\title{
Assessment of Communication Skills of Physical Education and Sport Students in Turkish Universities
}

\author{
Ali Dursun Aydin \\ School of Physical Education and Sports, Kafkas University Sarıkamış, Turkey
}

Copyright (C) 2015 by authors, all rights reserved. Authors agree that this article remains permanently open access under the terms of the Creative Commons Attribution License 4.0 International License

\begin{abstract}
This study assessed the communication skills of the students studying in physical education and sports schools in various universities in Turkey. A total of 1854 Physical Education and Sports students in five Turkish universities participated in the study. The instrument used to gather information for this study comprised the demographic information of participants and Communication Skills Assessment Scale (CSAS) composed of 25 items. The 5 point likert-type scale was developed by Korkut in 1996 and did not include reverse expressive items, and its assessment was carried out by the sum of scores on all items. Görmüş et al in 2003 determined the CSAS cronbach's alpha value as .841 in their study they carried out with the participation of 187 participants. After being transferred to the computer environment, the obtained data were subjected to various statistical processes. Accordingly, distribution analysis of the data was carried out at first and in accordance with the result obtained, parametric statistical applications were initiated. Frequency analysis was used in the assessment of participants' demographic data, t-test was used for the determination of the relationship between gender and variables, one-way analysis of variance was used for the determination of relationship between school, department, grade and age groups with variables, and tukey's test was used for the determination of the fact that from which group was the possible relationship resulted. According to the results, communication skills of the participants were at high level. According to the results obtained in the study, it was observed that, among the participants, 18 Mart University students $(X=75,262 \pm 10,173)$ had lower averages on the basis of communication skills compared to the students of Firat University $(X=77,532 \pm 10,670)$, İnönü $(X=80,946 \pm 9,003)$ and Kafkas University $(X=77,501 \pm 17,877)$. On the other hand, it was seen that Anadolu University students $(X=75,181 \pm 10,321)$ had lower average of communication skills compared to the students of Firat, İnönü and Kafkas Universities, and Firat University students had lower averages compared to İnönü University students.
\end{abstract}

Keywords Physical Education, Communication Skills, University

\section{Introduction}

Communication is the process of mutual transfer of feelings and thoughts, which has been the most important instrument in the formation of accumulation of knowledge which can be transferred from past to present by the people who are social beings. It is possible to say that communication skills that people have and can improve through education has become even more important within the context of rapidly developing technology and social changes in today's world.

The word of "communication" which was derived from the Latin word of "communis" and which is used as the equivalent of transmission refers to a partnership, association and socialization as a meaning [1].

There have been a variety of definitions for communication. Coming to an agreement on the common meaning of transmitted feeling, thought, attitude, knowledge and behaviors in these definitions constitutes the common point [2]. In traditional sense, communication function is generally seen as the mutual exchange of something [3].

Transferring of knowledge, feelings and skills to communication by using symbols and attributing meanings to it such as seeking meaning and case exchange are possible [4] [5]. Dökmen [6] defines the communication as a process in which participants produce knowledge/symbol and transmit them to each other, and they try to interpret and understand these messages.

Preventing the problems that may arise in this process could prevent the lack of communication in relationships among people, and accordingly could make relationships more reliable. Furthermore, the resolution of problems that may arise among individuals is associated with the well expression of this problem [7]. People can ensure this just by being conscious of some communication skills.

Human is a social being and survives in social structures (in organizations) he/she forms. Relationships and interactions within these structures are only possible with 
communication. Communication is one of the most important factors which is necessary for human to adapt to the environment [8]. Various studies were carried out in order to assess the effectiveness of communication skills training programs to develop communication skills and it was generally observed that communication skills training programs really develops communication skills [8] [9] [10] [7] [11] [12].

Effective communication skills could have facilitating characteristic of human relations and relationships in all professional fields. Especially those who work in professional fields that require more coexistence with people should have more full knowledge of communication skills [12].

Sport is a social environment in which more than one people work in coordination for a common purpose. Therefore, one of the keys to success in the field of sport is possible with effective communication as in all other fields. It can be said that it is a necessity for teachers, trainers and managers giving service in the field of sport have effective communication skills to be successful in their professions.

It is believed that physical education teachers, trainers and sport managers who can be said to work in environments with intensive human relations should have the abilities to facilitate human relations. In sport environments where people are allowed to perform by seeing, hearing and experiencing and where individual differences are not ignored, learning the skills that will make the communication effective and transferring them into the social life can be ensured. Therefore, training physical education teachers, trainers and sport managers as equipped in this regard is considered to be significant in order to provide communication skills for individuals with whom they have relations. [13]

With reference to these information, the purpose of the study is to determine the communication skills of the students studying in physical education and sports schools of different universities in Turkey and to assess them according to various demographic variables.

\section{Materials and Method}

This study discusses the communication skills of the students studying in physical education and sports schools in various universities in Turkey in 2014. Atotal of, 1854 students studying in Physical Education and Sports Schools in Anadolu University, Çanakkale 18 Mart University, Fırat University, İnönü University and Kafkas University, participated in the study. The questionnaire form used by the researcher in order to determine the participants' personal information, opinions and attitudes was composed of two sections. The first one of these sections included the demographic items such as age, gender, university, department and grade, and the second one included the items related to communication skills. The form used was composed of 30 items in total. Communication Skills
Assessment Scale (CSAS) in the second section of the form was composed of 25 items. The 5 point likert-type scale was developed by Korkut [14] in 1997 and did not include reverse expressive items, and its assessment was carried out by the sum of scores on all items. Görmüş et al in 2003 determined the CSAS cronbach's alpha value as .841 in their study they carried out with the participation of 187 participants [15].

After being transferred to the computer environment, the obtained data were subjected to various statistical processes. Accordingly, distribution analysis of the data was carried out at first and in accordance with the result obtained, parametric statistical applications were initiated. Frequency analysis was used in the assessment of participants' demographic data, t-test was used for the determination of the relationship between gender and variables, one-way analysis of variance was used for the determination of relationship between school, department, grade and age groups with variables, and Tukey's test was used for the determination of the fact that from which group was the possible relationship resulted. Finally, Pearson correlation analysis was carried out for the determination of the direct relation among variables.

\section{Findings}

Table 1. Demographic Characteristics of the Participants

\begin{tabular}{|c|c|c|c|}
\hline Factor & Variable & $\mathbf{n}$ & $\%$ \\
\hline \multirow{6}{*}{ University } & Kafkas University & 434 & $\% 23,4$ \\
\hline & İnönü University & 357 & $\% 19,3$ \\
\hline & Çanakkale University & 335 & $\% 18,1$ \\
\hline & Anadolu University & 346 & $\% 18,7$ \\
\hline & Firat University & 382 & $\% 20,6$ \\
\hline & Total & 1854 & $\% 100$ \\
\hline \multirow{4}{*}{ Department } & PES Teaching & 682 & $\% 36,8$ \\
\hline & Sports Management & 627 & $\% 33,8$ \\
\hline & Coaching training & 545 & $\% 29,4$ \\
\hline & Total & 1854 & $\% 100$ \\
\hline \multirow{5}{*}{ Grade } & 1. Grade & 484 & $\% 26,1$ \\
\hline & 2. Grade & 485 & $\% 26,2$ \\
\hline & 3. Grade & 478 & $\% 25,8$ \\
\hline & 4. Grade & 407 & $\% 22,0$ \\
\hline & Total & 1854 & $\% 100$ \\
\hline \multirow{3}{*}{ Gender } & Male & 1171 & $\% 63,2$ \\
\hline & Female & 683 & $\% 36,8$ \\
\hline & Total & 1854 & $\% 100$ \\
\hline \multirow{4}{*}{ Age } & $18-20$ years & 422 & $\% 22,8$ \\
\hline & $21-23$ years & 901 & $\% 48,6$ \\
\hline & Aged 24 and above & 531 & $\% 28,6$ \\
\hline & Total & 1854 & $\% 100$ \\
\hline
\end{tabular}


When analyzed the table, it is seen that most of the participants are from Kafkas University. Males form the majority in the study in which Physical Education and Sport Teaching students participated at the most.

Table 2. Participants' Communication Skills Averages.

\begin{tabular}{cccc}
\hline Factor & n & Average & Standard deviation \\
\hline $\begin{array}{c}\text { Communication } \\
\text { skills }\end{array}$ & 1854 & 77,333 & 10,705 \\
\hline
\end{tabular}

According to the table, the participants' communication skills are high.
Table 3. T- Test of Comparison of Participants' Communication Skills According to Gender.

\begin{tabular}{cccccc}
\hline $\begin{array}{c}\text { Communication } \\
\text { skills }\end{array}$ & N & Average & $\begin{array}{c}\text { Standard } \\
\text { deviation }\end{array}$ & t & $\mathbf{p}$ \\
\hline Male & 1171 & 76,266 & 10,870 & 5,702 &, $017^{*}$ \\
Female & 681 & 79,168 & 10,162 & & \\
\hline
\end{tabular}

*significant at $\mathrm{p}<.05$

According to table, it is seen that there are statistically significant differences between the communication skills averages of the participants on the basis of gender. The communication skills average of the male participants is higher compared to female.

Table 4. One - Way Anova of Comparison of the Participants' Communication Skills Averages According to the Universities Where They Study

\begin{tabular}{|c|c|c|c|c|c|c|}
\hline & University & $\mathbf{n}$ & Average & $\begin{array}{l}\text { Standard } \\
\text { deviation }\end{array}$ & $\mathbf{F}$ & $\mathbf{p}$ \\
\hline \multirow{7}{*}{ Communication Skills } & 18 Mart University & 335 & 75,262 & 10,173 & \multirow{7}{*}{17,454} & \multirow{7}{*}{, $000^{*}$} \\
\hline & Anadolu University & 346 & 75,181 & 10,321 & & \\
\hline & Firat University & 381 & 77,532 & 10,670 & & \\
\hline & & & & & & \\
\hline & İnönü University & 357 & 80,946 & 9,003 & & \\
\hline & Kafkas University & 433 & 77,501 & 11,877 & & \\
\hline & Total & 1852 & 77,333 & 10,705 & & \\
\hline
\end{tabular}

*Significant at $\mathrm{p}<.05$

According to table, it is seen that there are statistically significant differences between the participants' communication skills according to the universities where they study $(\mathrm{p}<0,05)$. The results of multiple comparison carried out for determining the source of the said difference is given in Table 5.

Table 5. Post Hoc test (Tukey test) of Participants' Communication Skills Averages According to the Universities.

\begin{tabular}{|c|c|c|c|c|}
\hline & \multicolumn{4}{|c|}{ Post Hoc (Tukey test) } \\
\hline & \multicolumn{2}{|c|}{ Comparison } & \multirow{2}{*}{$\begin{array}{c}\text { Difference Between Averages } \\
, 080\end{array}$} & \multirow{2}{*}{$\frac{\text { Significance }}{1,00}$} \\
\hline \multirow{10}{*}{ Communication Skills } & 18 Mart University & Anadolu University & & \\
\hline & & Furat University & $-2,27$ &, $000 *$ \\
\hline & & İnönü University & $-5,68$ &, $000^{*}$ \\
\hline & & Kafkas University & $-2,23$ &, $029 *$ \\
\hline & Anadolu University & Furat University & $-2,35$ &, $022 *$ \\
\hline & & İnönü University & $-5,76$ &, $000 *$ \\
\hline & & Kafkas University & $-2,31$ &, $019^{*}$ \\
\hline & Furat University & İnönü University & $-3,41$ &, $000 *$ \\
\hline & & Kafkas University &, 031 & 1,000 \\
\hline & İnönü University & Kafkas University & 3,44 &, $000^{*}$ \\
\hline
\end{tabular}

\footnotetext{
*Significant at $\mathrm{p}<.05$
}

According to table, it was observed that, among the participants, 18 Mart University students $(X=75,262 \pm 10,173)$ had lower averages on the basis of communication skills compared to the students of Frrat University $(X=77,532 \pm 10,670)$, İnönü $(X=80,946 \pm 9,003)$ and Kafkas University $(X=77,501 \pm 17,877)$. On the other hand, it was seen that Anadolu University students $(X=75,181 \pm 10,321)$ had lower average of communication skills compared to the students of Firat, İnönü and Kafkas Universities, and Fırat University students had lower averages compared to İnönü University students. 
Table 6. One - Way Anova Comparison of the Participants' Communication Skills Averages According to Departments Where They Receive Training.

\begin{tabular}{lcccccc}
\hline & Department & n & Average & Standard deviation & F & p \\
\hline & Coaching training & 544 & 74,645 & 9,694 & & \\
Communication Skills & P.E.S. Teaching & 681 & 78,384 & 11,678 & 24,947 &, 000 \\
& Sport Management & 627 & 78,524 & 10,014 & \\
& Total & 1852 & 77,333 & 10,705 & \\
\hline
\end{tabular}

*Significant at $\mathrm{p}<.05$

In Table 6, it is seen that there are statistically significant differences between the participants' communication skills according to the departments where they receive training $(p<0,05)$. The results of multiple comparison carried out for determining the source of the said difference is given in Table 7.

Table 7. Post Hoc test (Tukey test) of Participants' Communication Skills Averages According to Departments where They Receive Training.

\begin{tabular}{lccrr}
\hline & \multicolumn{4}{c}{ Post Hoc (Tukey test) } \\
\hline \multirow{3}{*}{ Communication Skills } & \multicolumn{2}{c}{ Comparison } & Difference Between Averages & Significance \\
\cline { 2 - 6 } & \multirow{2}{*}{ Coaching training } & B.E.S. Teaching & $-3,739$ &, $000^{*}$ \\
\cline { 2 - 6 } & P.E.S. Teaching & Sports Management & $-3,879$ &, $000^{*}$ \\
\hline
\end{tabular}

*Significant at $\mathrm{p}<.05$

According to table, it was observed that, among the participants, Coaching Training Department students ( $\mathrm{X}=76,645 \pm 9,694)$ had lower averages on the basis of communication skills compared to the students of Physical Education and Sports Teaching Department $(X=78,384 \pm 11,678)$ and Department of Sport Management $(X=78,524 \pm 10,014)$.

Table 8. One - Way Anova of Comparison of the Participants' Communication Skills Averages According to Their Grades.

\begin{tabular}{|c|c|c|c|c|c|c|}
\hline & Grade & $\mathbf{n}$ & Average & Standard deviation & $\mathbf{F}$ & p \\
\hline \multirow{5}{*}{ Communication Skills } & 1. Grade & 483 & 78,128 & 10,434 & \multirow{5}{*}{1,443} & \multirow{5}{*}{,229 } \\
\hline & 2. Grade & 485 & 77,373 & 10,320 & & \\
\hline & 3. Grade & 477 & 76,800 & 11,943 & & \\
\hline & 4. Grade & 407 & 76,968 & 9,888 & & \\
\hline & Total & 1852 & 77,333 & 10,705 & & \\
\hline
\end{tabular}

In Table 8, it is seen that there are not statistically significant differences between the participants' communication skills according to their grades. $(\mathrm{p}<.05)$

Table 9. One - Way Anova Comparison of the Participants' Communication Skills Averages According to Age Groups.

\begin{tabular}{ccccccc}
\hline & Age Group & $\mathbf{n}$ & Average & Standard deviation & F & p \\
\hline \multirow{3}{*}{ Communication Skills } & $\mathbf{1 8 - 2 0}$ & 421 & 78,997 & 9,388 & & \\
& $\mathbf{2 1 - 2 3}$ & 901 & 77,096 & 11,097 & 7,037 &, $001^{*}$ \\
& $\mathbf{2 4 +}$ & 530 & 76,415 & 10,878 & & \\
\hline
\end{tabular}

*Significant at $\mathrm{p}<.05$

In Table 9, it is seen that there are statistically significant differences between the participants' communication skills according to age group $(\mathrm{p}<0,05)$. The results of multiple comparison carried out for determining the source of the said difference is given in Table 10 .

Table 10. Post Hoc test (Tukey test) of Participants' Communication Skills Averages According to Age Groups.

\begin{tabular}{lcccrc}
\hline & \multicolumn{5}{c}{ Post Hoc (Tukey test) } \\
\hline \multirow{3}{*}{ Communication Skills } & \multicolumn{2}{c}{ Comparison } & Difference Between Averages & Significance \\
\cline { 2 - 6 } & $\mathbf{1 8 - 2 0}$ & $\mathbf{2 1 - 2 3}$ & 1,901 &, $007^{*}$ \\
& & $\mathbf{2 4 +}$ & 2,582 &, $001^{*}$ \\
\cline { 2 - 6 } & & $\mathbf{2 1 - 2 3}$ & $\mathbf{2 4}$ &, 681 &, 473 \\
\hline
\end{tabular}


According to table, it was observed that, among the participants, students in the 18-20 age group $(X=78,997 \pm 9,388)$ had higher averages on the basis of communication skills compared to the students of 21-23 age group $(X=77,096 \pm 11,097)$ and 24 years and above $(X=76,415 \pm 10,878)$. These two pairs of groups account for the significant difference obtained on table 9 . Students aged 21-23 compared with those of $24+$ did not constitute to the observed difference.

\section{Discussion and Result}

Various results were obtained in this study in which the communication skills of the graduate students studying in physical education and sports department of various universities in Turkey were investigated. First of all, it was observed that the result obtained was at high level when analyzed the communication skill averages of all participants $(X=77,333 \pm 10,705)$. When analyzed the relevant literature, it was seen that the populations of the studies carried out on the issue were not greater than this study, however, the average values obtained showed parallelism with the results of this study. [16] [17] [18] [19] [20]

According to the results obtained, a statistically significant difference was not observed between the variable of gender and communication skill averages of the participants. However, the communication skills average of the male participants was higher compared to female. Dilekmen et al. [19], in their study in which they investigated the communication skills of university students, revealed that there was not a significant difference on the basis of gender, and stated that the differentiation of communication skill concept with the variable of gender was normal. Y1lmaz et al. [18] obtained results similar to those in this study on the basis of gender in their study of communication skills they carried out on physical education and sports sciences students of different universities.

According to the results obtained in the study, it was observed that, among the participants, 18 Mart University students $(X=75,262 \pm 10,173)$ had lower averages on the basis of communication skills compared to the students of Firat University $(X=77,532 \pm 10,670)$, İnönü $(X=80,946 \pm 9,003)$ and Kafkas University $(X=77,501 \pm 17,877)$. On the other hand, it was seen that Anadolu University students $(X=75,181 \pm 10,321)$ had lower average of communication skills compared to the students of Frrat, İnönü and Kafkas Universities, and Frat University students had lower averages compared to İnönü University students. According to table, it was observed that, among the participants, Coaching Training Department students $(X=76,645 \pm 9,694)$ had lower averages on the basis of communication skills compared to the students of Physical Education and Sports Teaching Department $(\mathrm{X}=78,384 \pm 11,678)$ and Department of Sport Management $(X=78,524 \pm 10,014)$. Kilcigil et al (2009) reached significant differences between universities and departments in terms of communication skills in their study in which they investigated the communication skills of physical education and sport sciences students of two different universities.[21]

According to the findings of the study, it was observed that, among the participants, students in the 18-20 age group $(X=78,997 \pm 9,388)$ had higher averages on the basis of communication skills compared to the students of 21-23 age group $(X=77,096 \pm 11,097)$ and 24 years and above $(X=76,415 \pm 10,878)$. Y1lmaz and Çimen obtained different results which were not statistically significant in their study they carried out on physical education teacher candidates in 2008.[22]

As a result, it was observed in the study carried out that participants had a high level of communication skills, and that the obtained averages were statistically significantly differentiated on the basis of university, department and age.

\section{REFERENCES}

[1] Yatkın, A. Halkla İlişkiler ve İletişim, Nobel Yayınları, Ankara 2003.

[2] Ersanlı, K., Balcı, S. "İletişim Becerileri Envanterinin Geliştirilmesi: Geçerli ve Güvenirlik Çalışması". Türk Psikolojik Danışma ve Rehberlik Dergisi. Vol.2, 7-13, 1998.

[3] Oskay Ü. İletişimin ABC'si.[ABC of Communication] Ankara: Simavi Yayınları; 1994.

[4] Cüceloğlu, D. (2002). İletişim Donanımları, İstanbul, Remzi Kitabevi.

[5] Dökmen, Ü. (2002). İletisim çatısmaları ve empati. Communicative Conflicts and Empathy), Sistem Yay, Istanbul.

[6] Cüceloğlu, D. Yeniden insan insana, 15. Basım, Remzi Kitabevi, İstanbul 2013.

[7] Riesch, S. K., Henriques, J., Chanchong, W. 2003, Effects of Communication Skills Training on Parents and Young Adolescents From Extreme Family Types. Journal of Child and Adolescent Psychiatric Nursing. Vol.6, 162-175.

[8] Yüksel, Ş. F. Grupla İletişim Becerileri Eğitiminin Üniversite Öğrencilerinin İletişim Becerileri Düzeylerine Etkisi. Gazi Üniversitesi Sosyal Bilimler Enstitüsü. Doktora Tezi, Ankara, 1997.

[9] Sızak, M. Bir İletişim Becerileri Programının Engelli Çocukların Ergen Kardeşlerine ve Ailelerine Etkisi.: Orta Doğu Teknik Üniversitesi Sosyal Bilimler Enstitüsü. Yüksek Lisans Tezi, Ankara, 1999.

[10] Demirci, E. E. İletişim Becerileri Eğitiminin Mesleki Eğitim Merkezine Devam Eden Genç İşçilerin İletişim Becerilerini Değerlendirmelerine Etkisi. Hacettepe Üniversitesi Sosyal Bilimler Enstitüsü. Yüksek Lisans Tezi, Ankara, 2002.

[11] Deniz, İ. İletişim Becerileri Eğitiminin İlköğretim 8. Sınıf Öğrencilerinin İletişim Becerisi Düzeylerine Etkisi. Gazi Üniversitesi Eğitim Bilimleri Enstitüsü. Yüksek Lisans Tezi. Ankara, 2003. 
[12] Korkut, F. 2005, Yetişkinlere Yönelik İletişim Becerileri Eğitimi. Hacettepe Üniversite Eğitim Fakültesi Dergisi. Say1:28, 143-149.

[13] TEPEKÖYLÜ, Ö., SOYTÜRK, M., ÇAMLIYER, H., "Beden Eğitimi ve Spor Yüksekokulu (BESYO) Öğrencilerinin İletişim Becerisi Algılarının Bazı Değişkenler Açısından İncelenmesi "SPORMETRE Beden Eğitimi ve Spor Bilimleri Dergisi, 2009, VII (3) 115-124

[14] Korkut, F. Üniversite Öğrencilerinin İletişim Becerilerinin Değerlendirilmesi. IV. Ulusal Eğitim Bilimleri Kongresi Bildirileri. Anadolu

[15] Görmüş, A. Ş., Aydın, S., Ergin, G. İşletme Bölümü Öğrencilerinin İletişim Becerilerinin Cinsiyet Rolleri Bağlamında İncelenmesi. Sosyal Bilimler Dergisi, XV(1), 109-128. (2013).

[16] Saracalığlu, A,. Yenice, N., Karasakaloğlu, N. ÖĞRETMEN ADAYLARININ İLETISSIM VE PROBLEM ÇÖZME BECERILERİ ILE OKUMA İLGİ VE ALIŞKANLIKLARI ARASINDAKİ İLIŞKİ Yüzüncü Y1l Üniversitesi, Eğitim

[17] Çetinkaya, Ö,. Alparslan A,M. DUYGUSAL ZEKÂNIN İLETISTIM BECERİLERİ ÜZERINE ETKİSI: ÜNIVERSITE
ÖĞRENCILERİ ÜZERINNDE BİR ARAŞTIRMA Süleyman Demirel Üniversitesi İktisadi ve İdari Bilimler Fakültesi Dergisi Y.2011, C.16, S.1 s.363-377.

[18] Çetinkaya, Z. TÜRKÇE ÖĞRETMEN ADAYLARININ İLETISIM BECERILERINE İLISKIN GÖRÜSLERININ BELIRLENMESİ Mayıs 2011 Cilt:19 No:2 Kastamonu

[19] Bingöl, G., Demir, A. Amasya sağlık yüksekokulu öğrencilerinin iletişim Becerileri Göztepe Tip Dergisi 26(4):152-159, 2011

[20] Yılmaz, İ,. Yoncalık, O., Çimen, Z. İLETIŞ̧iM BECERİSI İLE ÖĞRETIMDE YETERLIK ARASINDAKİ İLISSININ ÖĞRENCİ ALGILARINA GÖRE DEĞERLENDİİLMESI (Beden Eğitimi ve Spor Alanı) SPORMETRE Beden Eğitimi ve Spor Bilimleri Dergisi, 2010, VIII (4) 143-150

[21] Kılcıgil, E,. Bilir, P., Özdinç, Ö., Eroğlu, K., Eroğlu, B. İKİ FARKLI UUNIVERSITENIN BEDEN EGITIMIVE SPOR YÜKSEKOKULU ÖĞRENCILERININ ILNETISSIM BECERILERININ DEĞERLENDİRILMESI SPORMETRE Beden Eğitimi ve Spor Bilimleri Dergisi, 2009, VII (1) 19-28

[22] Yılmaz, İ., Çimen, Z. Beden Eğitimi Öğretmen Adaylarının İletişim Becerisi Düzeyleri, Atatürk Üniversitesi Beden Eğitimi ve Spor Bilimleri Dergisi, Vol.10,3 pp3-14, 2008. 